\title{
IDENTIFIKASI MiskonSEPSi MAHASISWA MENGGUNAKAN CRI PADA MATA KULIAH KALKULUS II
}

\section{IDENTIFICATING STUdENTS' MisconCEPTION USING CRI ON 2 ${ }^{\text {ND }}$ CALCULUS COURSE}

\author{
Abdul Mujib \\ Universitas Muslim Nusantara Al-Washliyah \\ Medan, Sumatera, Indonesia \\ mujib@umnaw.ac.id
}

\begin{abstract}
Abstrak
Miskonsepsi merupakan masalah yang selalu muncul dalam kegiatan belajar mengajar. Untuk itu, penelitian ini bertujuan untuk mengidentifikasi miskonsepsi mahasiswa yang sedang mengambil matakuliah kalkulus II. CRI (Certainty of Response Index) digunakan untuk mengidentifikasi mahasiswa yang mengalami miskonsepsi, tidak paham konsep, dan sama sekali tidak tahu konsep. Penelitian ini melibatkan 20 responden yang sedang mengambil matakuliah kalkulus II. Instrument yang digunakan adalah tes diasnogtik dalam bentuk essay. Selain menjawab soal, mahasiswa juga diminta untuk menuliskan tingkat keyakinan kebenaran dari jawaban mereka. Selain itu, wawancara terstruktur juga digunakan untuk mengvalidasi tingkat keyakinan mahasiswa dan penyebab terjadinya miskonsepsi. Hasil penelitian menunjukkan bahwa CRI dapat dengan mudah membedakan siswa yang memahami konsep dengan baik dengan mahasiswa yang mengalami kesalahan. Berdasarkan analisis kesalahan mahasiswa diperoleh $46 \%$ mahasiswa mengalami miskonsepsi, 53,4\% mahasiswa tidak mengetahui konsep dan 0,6\% mahasiswa yang sama sekali tidak tahu konsep (lucky guess).

Kata Kunci: Miskonsepsi, CRI (Certainty of Response Index), Kalkulus II.
\end{abstract}

\begin{abstract}
Misconception is an issue that always arises in teaching and learning activities. Therefore, this study aims to identify the misconception of students who are taking calculus II courses. CRI (Certainty of Response Index) is used to identify students with misconceptions, not understanding concepts, and not knowing concepts at all. This study involved 20 respondents who are taking calculus II courses. Instrument used is diagnogtic test in essay form. In addition to answering questions, students are also asked to write down the level of confidence in their answers. In addition, structured interviews are also used to validate student confidence and the causes of misconceptions. The results show that CRI can easily distinguish students who understand the concept well with students who experience errors. Based on the student error analysis, $46 \%$ of students have misconception, $53,4 \%$ of students do not know concept and $0,6 \%$ of students do not know concept (lucky guess).

Keyword: Misconceptions, CRI (Certainty of Response Index), Calculus II.
\end{abstract}

\section{Pendahuluan}

Dalam kegiatan belajar mengajar tidak akan terpisah dengan munculnya masalah. Salah satu masalah yang selalu mengikuti dalam kegiatan belajar mengajar adalah miskonsepsi. Walaupun tidak semua peserta didik dalam kelas itu mengalaminya, setidaknya miskonsepsi ini 
selalu terjadi dalam kegiatan belajar mengajar. Beberapa penelitian menunjukkan bahwa salah satu sumber kesulitan utama dalam pelajaran matematika adalah akibat terjadinya kesalahan konsep atau miskonsepsi pada diri siswa (Clement 1982; Joseph, 1987; Ryan \& McCrae, 2005; Riccommini, 2005; Brown \& Quinn, 2006; Luneta \& Makonya 2010). Banyak hal yang menyebabkan siswa mengalami miskonsepsi. Miskonsepsi ini terjadi karena diri siswa itu sendiri, cara mengajar guru, buku teks yang digunakan serta factor lingkungan. miskonsepsi pada diri siswa berasal dari pengalaman sehari-hari ketika berinteraksi lingkungan atau pengalaman belajar sebekumnya. Dengan pengalaman itu maka dibenak para siswa sudah terbentuk suatu intuisi dan "teori siswa" mengenai konsep-konsep matematika, yang sudah tentu intuisi dan teori yang terbentuk tersebut belum tentu benar. Ketika intuisi yang terbentuk tersebut salah, maka akan sulit sekali untuk diperbaiki, karena tanpa disengaja telah terjadi secara konsisten konsep-konsep matematika yang salah tersebut menjadi pegangan hidupnya. Dengan adanya miskonsepsi ini, sangat menghambat pada proses penerimaan dan asimilasi pengetahuan-pengetahuan baru dalam diri siswa, sehingga akan menghalangi keberhasilan siswa dalam proses belajar lebih lanjut (Klammer, 1998). Miskonsepsi ini merupakan masalah yang harus dicari solusi alternatifnya. Walaupun tidak mudah, masalah ini telah banyak dilakukan penelitian untuk mencari solusi terbaik yang mungkin.

Namun, bicara tentang upaya penanggulangan miskonsepsi, sebenarnya terdapat masalah yang lebih mendasar dan sangat urgen dalam masalah miskonsepsi ini, yaitu masalah pengidentifikasian terjadinya miskonsepsi. Hingga saat ini masih terdapat kesulitan dalam membedakan antara siswa-siswa yang miskonsepsi dan yang tidak tahu konsep. Tanpa dapat membedakan diantara keduanya, akan sulit untuk menentukan langkah penanggulangannya, sebab cara penanggulangan untuk siswa yang mengalami miskonsepsi akan berbeda dengan siswa yang tidak mengalami miskonsepsi. Kesalahan dalam mengidentifikasi siswa menyebabkan kesalahan dalam memberikan solusi dalam menanggulanginya.

Sehingga menghasilkan solusi yang tidak tepat dan kurang memuaskan. Oleh Karena itu, pengetahuan mengidentifikasi miskonsepsi secara tepat menjadi pengetahaun yang penting bagi guru atau dosen.

Usaha untuk mengidentifikasi masalah miskonsepsi telah banyak dilakukan, namun hingga saat ini masih terdapat kesulitan dalam membedakan antara siswa yang mengalami miskonsepsi dengan yang tidak tahu konsep. Kesalahan dalam mengidentiffikasi siswa yang mengalami miskonsepsi akan menyebabkan kesalahan dalam penangulangannya, Karena penanggulangan siswa yang mengalami miskonsepsi sangat berbeda dengan siswa 
yang tidak tahu konsep. Salah satu alternatif yang digunakan untuk mengidentifikasi miskonsepsi adalah teknik Certainly of Response Index (CRI) yang dikembangkan oleh Saleem Hasan (1999).

Oleh Karena itu, tujuan dari penelitian ini adalah untuk mengidentifikasi miskonsepsi mahasiswa pada matakuliah kalkulus II dengan menggunakan teknik CRI.

\section{A. Analisis Kesalahan Mahasiswa}

Kesalahan penyelesaian soal-soal matematika masih sering ditemukan dalam pekerjaan mahasiswa, dari kesalahan yang dilakukan mahasiswa sebagai sarana untuk memperbaiki pembelajaran yang ada dan mengatasi kesalahan yang dilakukan mahasiswa dalam menyelesaikan soal matematika. Analisis kesalahan adalah suatu proses yang terdiri atas langkah langkah yang berbeda, yakni untuk identifikasi, klarifikasi penjelasan, koreksi, penilaian, terapi, dan pencegahan timbulnya kesalahan. Kesalahan-kesalahan mahasiswa ini bisa terjadi dikarenakan beberapa hal diantaranya karena konsep, konsepsi, prakonsepsi dan miskonsepsi.

Konsep adalah benda-benda, kejadiankejadian, situasi-situasi, atau ciri-ciri yang memiliki ciri khas dan yang mewakili dalam setiap budaya oleh suatu tanda atau simbol (objects, events, situation, or properties that possess common critical attributes and are designated in any given culture by some accepted sign or symbol) (Ausubel, dkk 1978). Jadi konsep merupakan abstraksi dari ciri-ciri sesuatu yang mempermudah komunikasi antara manusia dan yang memungkinkan manusia berpikir (bahasa adalah alat berpikir). Jadi, konsep merupakan suatu objek yang mempunyai ciri-ciri yang sama, ide atau gagasan yang dibentuk berdasarkan pengalaman manusia untuk mempermudah komunikasi dan memungkinkan manusia berpikir sesuai dengan peristiwa atau fakta.

Konsepsi berasal dari kata 'to conceive' yang artinya menerima. Konsepsi setiap individu berbeda. Setiap mahasiswa sebelum memasuki perkuliahan ternyata mahasiswa sudah mempunyai konsepsi atau teori mengenai konsep-konsep matematika melalui pengalaman dan pengetahuan konsepsi. Konsepsi seseorang tentang matematika dapat di nilai benar bisa juga salah. Jika konsepsi mahasiswa sama dengan konsepsi matematikawan, maka konsepsi mahasiswa benar. Van Den Berg (1991), konsepsi adalah suatu konsep yang dimiliki seseorang memalui penalaran. Jadi, konsepsi merupakan konsep yang dimiliki seseorang melalui pemikiran dan penalaran sendiri, konsep tersebut bisa salah dan juga bisa benar.

Di dalam proses pembelajaran setiap mahasiswa sudah mempunyai pengetahuan awal dari pengalaman dan pembelajaran yang sudah didapat sebelumnya. Pengetahuan awal mahasiswa digunakan sebagai acuan bagi dosen dalam pembelajaran selanjutnya, sehingga pengetahuan awal atau 
prakonsepsi diartikan konsep yang dimiliki siswa sebelum proses pembelajaran berlangsung, meskipun mereka sudah pernah mendapatkan pembelajaran tersebut sebelumnya (Suparno, 2005). Dengan demikian, prakonsepsi merupakan konsep awal seseorang sebelum pembelajaran berlangsung atau tentang suatu objek.

Miskonsepsi atau salah konsep pada suatu konsep yang tidak sesuai dengan pengertian yang diterima para pakar dalam bidangnya, misalkan di dalam bidang matematika apabila konsep tidak sesuai dengan pengertian dalam matematika maka terjadi miskonsepsi atau salah konsep. Miskonsepsi juga dapat diartikan suatu pengertian yang tidak akurat tentang konsep yang salah, klasifikasi contoh-contoh yang salah tentang penerapan konsep, pemaknaan konsep yang berbeda dan hubungan konsep yang tidak benar. Hal serupa juga disampaikan oleh Brown (Suparno: 2005) menyatakan miskonsepsi merupakan penjelasan yang salah dan suatu gagasan yang tidak sesuai dengan pengertian ilmiah. Sekali miskonsepsi masuk dalam struktur kogniktif mahasiswa, maka berlanjut miskonsepsi. Jadi miskonsepsi adalah tafsiran atau persepsi yang kurang memadai terhadap suatu konsep. Seseorang mengalami miskonsepsi apabila konsepsi terhadap suatu konsep bertentangan dengan konsep para ilmuan. Suparno (2005) mengidentifikasi ada lima sebab utama miskonsepsi dan masing masing ditimbulkan oleh sebab khusus.
Sebab utama terjadinya miskonsepsi adalah peserta didik, Pendidik (guru atau dosen), buku teks, cara mengajar.

Prakonsepsi, pemikiran asosiatif, pemikiran humanistik dari mahasiswa dapat juga menyebabkan miskonsepsi. Selain itu, Rasioning yang tidak lengkap, intuisi yang salah, tahap perkembangan koniktif, kemampuan, dan minat peserta didik juga dapat menimbulkan miskonsepsi. Factor lain yang menyebabkan miskonsepsi adalah pendidik. Masih adanya pendidik yang tidak menguasai bahan, tidak linier pada bidangnya, kurang mengungkapkan prakonsepsi siswa atau bahkan relasi guru tidak baik juga dapat menyebabkan miskonsepsi. Bahan ajar seperti buku teks, adanya penjelasan keliru, salah tulis terutama dalam rumus, Bahasa penulisan terlalu tinggi bagi siswa, dapat menyebabkan miskonsepsi.

\section{B. Tipe-tipe Kesalahan}

Kesalahan adalah penyimpanganpeyimpangan yang sifatnya sistematis, konsisten dan penggambaran kemampuan kemampuan mahasiswa dalam penyelasaian soal-soal kalkulus II. Di dalam penelitian ini menggunakan soal uraian, sehingga dalam penyelasaian soal mahasiswa dituntut untuk menuliskan cara penyelesaian berdasarkan pemikirannya dalam menyelesaikan soal dari pemikiran mahasiswa tersebut. Dengan melihat jawaban dari mahasiswa dapat diketahui jenis-jenis kesalahan yang dilakukan.

Menurut Clement (1981) tipe-tipe kesalahan sebagai berikut: 
- Coreless error, yaitu kesalahan karena kecerobohan atau kurang cermat. Kesalahan-kesalahan mahasiswa dalam menyelesaikan soal-soal matematika adalah tidak menguasai bahasa. Seperti mahasiswa tidak paham dengan pernyataan dalam soal matematika, tidak memahami arti kata, tidak menguasai konsep, dan kurang menguasai teknik berhitung.

- Weakness in process skill, yaitu kesalahan dalam keterampilan proses. Mahasiswa dalam menggunakan kaidah atau aturan sudah benar, tetapi melakukan kesalahan dalam melakukan perhitungan atau komputasi.

- Reading comprehension difficulty, yaitu kesalahan memahami soal. Mahasiswa sebenarnya sudah dapat memahami soal, tetapi belum menangkap informasi yang terkandung dalam pertanyaan, sehingga mahasiswa tidak dapat memproses lebih lanjut solusi dari permasalahan.

- Transform error, yaitu kesalahan dalam transformasi. Mahasiswa gagal dalam memahami soal-soal untuk diubah ke dalam kalimat matematika yang benar.

- Encoding error, yaitu kesalahan dalam menggunakan notasi. Mahasiswa melakukan kesalahan dalam menggunakan notasi yang benar. Di dalam mengerjakan mahasiswa menggunakan notasi yang salah.

\section{Analisis Miskonsepsi}

Saleem Hasan (1999) mengidentifikasi terjadinya miskonsepsi, sekaligus dapat membedakannya dengan tidak tahu konsep, dengan mengembangkan suatu metode identifikasi yang dikenal dengan istilah CRI (Certainty of Response Index). CRI merupakan ukuran tingkat keyakinan/ kepastian responden dalam menjawab setiap pertanyaan (soal) yang diberikan. CRI yang rendah menandakan ketidakyakinan konsep pada diri responden dalam menjawab suatu pertanyaan, sedangkan CRI yang tinggi mencerminkan keyakinan dan kepastian konsep yang tinggi pada diri responden. $\mathrm{CRI}$ dikembangkan dengan skala enam (05) seperti pada Tabel 1 berikut ini.

Tabel 1. Kriteria Skor CRI

\begin{tabular}{|cc|}
\hline CRI & Kriteria \\
\hline 0 & (Totally guessed answer) \\
\hline 1 & (Almost guess) \\
\hline 2 & (Not Sure) \\
\hline 3 & (Sure) \\
\hline 4 & (Almost certain) \\
\hline 5 & (Certain) \\
\hline
\end{tabular}

Skor nol berarti tidak tahu konsep sama sekali tentang teknik, metode, atau rumus yang diperlukan untuk menjawab suatu pertanyaan (jawaban dengan cara menebak), sementara skor 5 menandakan kepercayaan diri yang penuh atas kebenaran pengetahuan tentang teknik, metode, strategi, atau rumus yang dipergunakan untuk menjawab suatu pertanyaan. Dengan kata lain, skor CRI ini menunjukkan tingkat atau derajat keyakinan responden dalam meyelesaikan masalah atau menjawab pertanyaan yang diberikan. 
Jika derajat kepastiannya rendah (CRI 02), maka hal ini menggambarkan bahwa dalam menjawab soal dilakukan dengan cara menebak. Hal ini mencerminkan ketidaktahuan responden terhadap konsep yang mendasari penentuan jawaban. Jika CRI tinggi (CRI 3 - 5), maka responden memiliki tingkat kepercayaan diri (confidence) yang tinggi dalam menjawab soal atau pertanyaan. Ada dua kemungkinan tingkat kepercayaan diri tinggi disini, confidence bahwa jawabannya memang benar ang menunjukkan bahwa responden menguasai konsep dan memiliki strtategi yang tepat atau confidence bahwa jawabannya salah yang berarti adanya kesalahan-kesalahan konsep atau startegi yang responden gunakan dalam menjawab pertanyaaan. Dari analisis inilah, dapat dibedakan antara yang terjadi miskonsepsi dan tidak tahu konsep.

Berikut ini ketentuan untuk membedakan antara tahu konsep, miskonsepsi dan tidak tahu konsep untuk responden secara individu.

Tabel 2.

Ketentuan membedakan miskonsepsi, tidak tahu konsep, dan menguasai konsep responden secara individu

\begin{tabular}{ccc}
\hline $\begin{array}{c}\text { Kriteria } \\
\text { Jawaban }\end{array}$ & $\begin{array}{c}\text { CRI Rendah } \\
\text { (0-2) }\end{array}$ & CRI Tinggi (3-5) \\
\hline \multirow{3}{*}{$\begin{array}{c}\text { tidak tahu } \\
\text { kawaban } \\
\text { benar }\end{array}$} & $\begin{array}{c}\text { (lucky } \\
\text { guess) }\end{array}$ & $\begin{array}{c}\text { menguasai konsep } \\
\text { dengan baik }\end{array}$ \\
\hline $\begin{array}{c}\text { Jawaban } \\
\text { salah }\end{array}$ & $\begin{array}{c}\text { tidak tahu } \\
\text { konsep }\end{array}$ & terjadi \\
\hline
\end{tabular}

Sebagaimana Tabel 2 di atas, responden yang dapat dikategorikan mengalami miskonsepsi adalah mahasiswa yang salah dalam menjawab dan CRI yang dipilinnya kategori tinggi (3-5). Miskonsepsi tersebut, dapat berasal dari mahasiswa sendiri, dari dosen yang menyampaikan konsep yang keliru, metode mengajar yang kurang tepat, atau buku teks yang salah.

Tabel 3.

Ketentuan membedakan miskonsepsi, tidak tahu konsep, dan menguasai konsep responden secara Kelompok

\begin{tabular}{|c|c|c|}
\hline $\begin{array}{c}\text { Kriteria } \\
\text { Jawaban }\end{array}$ & $\begin{array}{l}\text { CRI Rendah } \\
(C R I<2,5)\end{array}$ & $\begin{array}{c}\text { CRI Tinggi (CRI > } \\
2,5)\end{array}$ \\
\hline $\begin{array}{c}\text { Jawaban } \\
\text { benar }\end{array}$ & $\begin{array}{c}\text { Jawaban benar } \\
\text { dan rata-rata } \\
\text { CRI rendah } \\
\text { berarti tidak } \\
\text { tahu } \\
\text { konsep (lucky } \\
\text { guess) }\end{array}$ & $\begin{array}{c}\text { Jawaban benar } \\
\text { dan rata-rata CRI } \\
\text { tinggi berarti } \\
\text { menguasai } \\
\text { konsep dengan } \\
\text { baik }\end{array}$ \\
\hline $\begin{array}{l}\text { Jawaban } \\
\text { salah }\end{array}$ & $\begin{array}{c}\text { Jawaban salah } \\
\text { dan rata-rata } \\
\text { CRI rendah } \\
\text { berarti tidak } \\
\text { tahu konsep }\end{array}$ & $\begin{array}{c}\text { Jawaban salah } \\
\text { dan rata-rata CRI } \\
\text { tinggi berarti } \\
\text { terjadi } \\
\text { miskonsepsi }\end{array}$ \\
\hline
\end{tabular}

Tabel 3 diatas merupakan pedoman menentukan responden secara berkelompok apakah terjadi miskonsepsi. Jawaban responden ditabulasi, setiap jawaban pertanyaan ditandai dengan skor 1 untuk jawaban benar, dan skor 0 untuk jawaban salah dan skor CRI (0 sampai 5). Untuk setiap pertanyaan yang diberikan, Rata-rata CRI untuk jawaban salah, untuk setiap pertanyaan yang diberikan diperoleh dengan cara membagi jumlah total skor CRI dengan banyaknya responden yang menjawab salah. Dengan cara yang sama untuk jawaban responden yang benar. 


\section{MetOde}

Sesuai tujuan penelitian maka penelitian menggunakan penelitian deskriptif kualitatif yang berupaya untuk mendeskripsikan miskonsepsi mahasiswa pada matakuliah kalkulus II. Dikatakan penelitian deskriptif karena peneliti melakukan analisis hanya sampai pada taraf deskripsi, yaitu menganalisis dan menyajikan fakta secara sistematik. Melalui pendekatan kualitatif dalam penelitian ini, semua fakta baik lisan maupun tulisan dari sumber manusia yang telah diamati dan dokumen terkait lainnya yang diuraikan apa adanya kemudian dikaji dan disajikan seringkas mungkin untuk menjawab pertanyaan penelitian.

\section{A. Responden}

Penelitian ini dilaksanakan di Program Studi Teknik Industri Semester dua di Institut Teknologi Nasional Bandung. Penelitian dilakukan selama satu semester

Tabel 4.

Pedoman Penskoran Tes Miskonsepsi

\begin{tabular}{|c|c|}
\hline Komponen penskoran & Skor \\
\hline $\begin{array}{l}\text { Jawaban mahasiswa memenuhi kriteria: } \\
\text { - } \quad \text { Mengimplementasikan konsep dan prosedur (stretegi) yang relevan dalam } \\
\text { memecahkan masalah } \\
\text { - } \quad \text { Mengetahui dan mengatasi kendala-kendala dalam memecahkan masalah. } \\
\text { - Jawaban dan prosedur benar, ada kesalahan kecil dalam perhitungan. }\end{array}$ & 4 \\
\hline $\begin{array}{l}\text { Strategi yang digunakan dalam memecahkan masalah sudah benar, namun solusi } \\
\text { secara keseluruhan belum benar: } \\
\text { - Terdapat miskonsepsi atau kesalahan dalam konsep yang relevan yang } \\
\text { diperlukan dalam memecahkan masalah. } \\
\text { - } \quad \text { Kurang mampu memahami kendala-kendaa dalam memecahkan masalah. } \\
\text { - } \quad \text { Menuliskan variable yang tak relevan. } \\
\text { - Jawaban secara kesulurah benar, namun tidak urut (ada tahapan yang di } \\
\text { hilangkan) }\end{array}$ & 3 \\
\hline $\begin{array}{l}\text { Strategi yang digunakan siswa dalam memecahkan masalah sudah tepat, tetapi } \\
\text { jawaban masih salah: } \\
\text { - } \quad \text { Siswa gagal mengenali beberapa konsep relevan yang diperlukan dalam } \\
\text { memecahkan masalah. }\end{array}$ & 2 \\
\hline
\end{tabular}

(16 pertemuan). Responden terdiri dari 25 mahasiswa dengan 5 mahasiswa kehadiran kurang dari 50\%, sehingga dipilih responden 20 mahasiswa yang aktif mengikuti perkuliahan kalkulus II.

\section{B. Instrumen Penelitian}

Untuk mengumpulkan informasi miskonsepsi mahasiswa pada matkauliah Kalkulus II, data observasi dikumpulkan dari hasil test Miskonsepsi. Sebagai data pendukung, juga dilakukan wawancara terstruktur untuk menggali informasi mengenai tingkat keyakinan mahasiswa dalam menjawab soal kesulitan mahasiswa memecahkan masalah, serta informasi lainnya yang kaitan.

Tes miskonsepsi terdiri dari 7 butir soal dan disusun untuk mengukur kemampuan mahasiswa pada matakuliah kalkulus II. Berikut ini tabel penskoran tes miskonsepsi 
Siswa gagal mengungkap kendala-kendala dalampemecahan masalah.

- Siswa gagal mengkaitkan variable-variabel yang relevan.

- Jawaban secara umum benar, tetapi tidak ada informasi bagaimana siswa memperoleh kebenaran jawaban tersebut.

Siswa menunjukkan usaha dalam memecahkan masalah, tetapi jawaban tidak benar:

- Siswa memahami kendala-kendala atau variable-variabel yang relevan dalam masalah, tetapi gagal memahami konsep-konsep yang relevan.

- $\quad$ Prosedur atau strategi yang digunakan tidak sesuai.

Respon siswa didiantaranya sebagai berikut:

- Jawaban kososng atau siswa hanya menulis ulang soal atau informasi yang adala dalam masalah.

- Jawaban salah tanpa ada tanpa ada informasi pendukung

- Jawaban siswa tidak ada kaitan dengan yang ditanyakan dalam masalah.

C. Teknik Analisis Data

Data observasi yang terkumpul dari hasil tes Miskonsepsi maupun wawancara dianalisis melalui langkah-langkah berikut:

- Melakukan tabulasi data hasil test miskonsepsi pada matakuliah kalkulus II.

- Mentranskrip hasil wawancara.

- Mengklasifi kasikan jenis-jenis miskonsepsi mahasiswa mencakup konsep, sub bahasan/materi yang masih sulit dimengerti mahasiswa dan langkah-langkah apa yang kurang dipahami mahasiswa dalam penyelesaian kasus/soal kalkulus II.

- Melakukan triangulasi data dari test miskonsepsi, hasil wawancara dan

Tabel 5.

Capain Mahasiswa terhadap Soal Kalkulus II

\begin{tabular}{lccc}
\hline \multicolumn{1}{l}{ Indikator Soal } & No Soall & Skor & $\begin{array}{c}\text { Capaian } \\
\text { (\%) }\end{array}$ \\
\hline $\begin{array}{l}\text { Menentukan } \\
\text { nilai integral } \\
\text { dengan }\end{array}$ & $1 \mathrm{a}$ & 2,35 & 58,75 \\
\cline { 2 - 4 } $\begin{array}{l}\text { memanfaatkan } \\
\text { teknik-teknik } \\
\text { integral } \\
\begin{array}{l}\text { subtitusi, } \\
\text { partial, }\end{array}\end{array}$ & $1 \mathrm{~b}$ & 2,00 & 31,25 \\
\hline
\end{tabular}

\section{Hasil dan Pembahasan}

Penelitian ini bertujuan untuk mengidentifikasi miskonsepsi mahasiswa ketika menyelesaikan masalah kalkulus II. Berikut ini akan dikaji miskonsepsi mahasiswa dalam memecahkan masalah kalkulus II.

\section{A. Deskriptif Data hasil penelitian}

Tes diagmostik miskonsepsi diberikan kepada mahasiswa yang terdiri dari 7 soal kalkuluas II. Berikut ini disajikan indicator tiap soal dan capaian kemampuan mahasiswa dalam menjawab soal tersebut:

\begin{tabular}{|c|c|c|c|}
\hline $\begin{array}{l}\text { rasional, } \\
\text { trigonometri. }\end{array}$ & & & \\
\hline \multirow{4}{*}{$\begin{array}{l}\text { Menentukan } \\
\text { turunan fungsi } \\
\text { transenden }\end{array}$} & $2 a$ & 2,60 & 65,00 \\
\hline & $2 b$ & 3,30 & 82,50 \\
\hline & $2 c$ & 2,00 & 50,00 \\
\hline & $2 d$ & 2,45 & 61,25 \\
\hline \multirow{3}{*}{$\begin{array}{l}\text { Menentukan } \\
\text { turunan partial } \\
\text { dan nilai } \\
\text { turunan } \\
\text { partial. }\end{array}$} & $3 a$ & 3,50 & 87,50 \\
\hline & $3 b$ & & \\
\hline & & 3,50 & 87,50 \\
\hline Menentukan & $4 a$ & 3,90 & 97,50 \\
\hline
\end{tabular}




\begin{tabular}{|lccc|}
\hline $\begin{array}{l}\text { nilai integral } \\
\text { rangkap dua }\end{array}$ & $4 b$ & 3,55 & 88,75 \\
\hline $\begin{array}{l}\text { Aplikasi } \\
\text { integral } \\
\text { rangkap 2 }\end{array}$ & $5 \mathrm{~b}$ & 3,70 & 92,50 \\
\cline { 2 - 4 } & $5 \mathrm{~b}$ & 3,70 & 92,50 \\
\hline $\begin{array}{l}\text { Menentukan } \\
\text { solusi } \\
\text { persamaan }\end{array}$ & $6 \mathrm{~b}$ & 3,35 & 83,75 \\
\hline
\end{tabular}

\begin{tabular}{|c|c|c|c|}
\hline $\begin{array}{l}\text { diferensial } \\
\text { orde satu }\end{array}$ & & & \\
\hline \multirow{2}{*}{$\begin{array}{l}\text { Menentukan } \\
\text { solusi } \\
\text { persamaan } \\
\text { diferensial } \\
\text { orde dua } \\
\end{array}$} & $7 a$ & 3,10 & 77,50 \\
\hline & $7 b$ & 3,45 & 86,25 \\
\hline Rataan & & & 73,89 \\
\hline
\end{tabular}

Secara diagram batang, Capaian mahasiswa pada matakuliah Kalkulus II disajikan pada gambar 1 berikut ini:

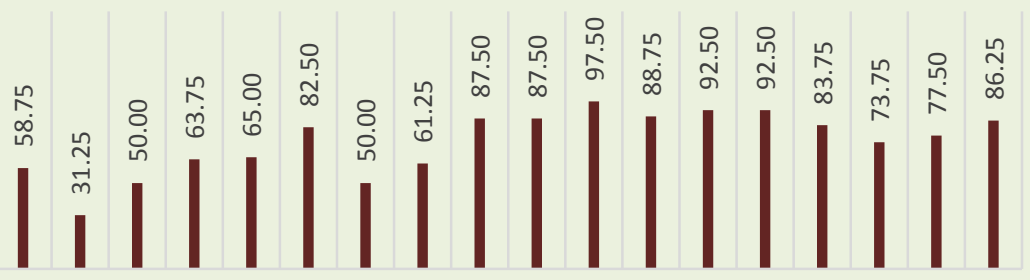

$\begin{array}{llllllllllllllllllllllll}1 A & 1 B & 1 C & 1 D & 2 A & 2 B & 2 C & 2 D & 3 A & 3 B & 4 A & 4 B & 5 A & 5 B & 6 A & 6 B & 7 A & 7 B\end{array}$

Gambar 1. Capaian Mahasiswa pada matakuliah Kalkulus II.

Berdasarkan tabel 5 dan gambar 1, no 7 merupakan aplikasinya, yang diketahui bahwa capaian tertinggi berkaitan dengan beberapa konsep diperoleh pada soal no 4 a yaitu $97,50 \%$ matematika dasar. Secara keseluruhan, tentang menentukan integral rangkap dua yang berarti hanya 2,5\% mahasiswa tiap item soal memiliki potensi kesalahan atau miskonsepsi bagi mahasiswa.

mengalami kesalahan atau miskonsepsi.

Sedangkan capaian terendah diperoleh pada soal no.1b yaitu $31,25 \%$ berkaitan dengan teknik integral fungsi rasional dengan demikian 68,75\% siswa mengalami kesalahan atau miskonsepsi. Secara keseluruhan, kemampuan pemecahan masalah mahasiswa mencapai 73,89\% atau dalam kategori sedang/cukup. Secara diagram, dari no 1 sampai dengan no 7, memiliki kecenderungan naik pencapaian kemampuan pemecahan masalah mahasiswa. Soal no 1 sampai dengan no 3 masih erat kaitannya dengan materi kalkulus I yaitu teknik integral dan turunan, sedangkan no 4 sampai dengan

\section{B. Identifikasi Miskonsepsi Mahasiswa secara individu}

Miskonsepsi terjadi pada mahasiswa yang mengalami kesalahan dalam menjawan soal tetapi memiliki tingkat keyakinan yang tinggi. Berdsasarkan pedoman peskoran siswa yang mungkin mengalami kesalahan ada pada interval skor $0-3$ dengan tingkat keyakinan pada interval $3-5$. Tingkat keyakinan mahasiswa dalam menjawab soal divalidasi kembali melalui wawancara untuk memastikan tingkat keyakinan yang dituliskan oleh mahasiswa dalam menjawab soal kalkulus II. Table 3 Berikut 
ini akan disajikan skor mahasiswa yang melakukan kesalahan dalam menjawab soal dan skor CRI setelah dilakukan wawancara pada tiap item soal.

Tabel 6.

Frekwensi mahasiswa yang mengalami miskonsepsi, tidak tahu konsep dan menebak jawaban (Lucky guess) per item soal

\begin{tabular}{|c|c|c|c|c|c|}
\hline $\begin{array}{c}\text { No. } \\
\text { Soa } \\
\text { I }\end{array}$ & $\begin{array}{c}\text { Miskonsep } \\
\text { si }\end{array}$ & $\begin{array}{c}\text { Tidak } \\
\text { tahu } \\
\text { konse } \\
\text { p }\end{array}$ & $\begin{array}{l}\text { Luck } \\
\text { y } \\
\text { gues } \\
\text { s }\end{array}$ & $\underset{\mathrm{h}}{\mathrm{Jumla}}$ & $\begin{array}{c}\text { No. } \\
\text { Soa } \\
\text { I }\end{array}$ \\
\hline \multirow[t]{4}{*}{1} & $a$ & 3 & 9 & 0 & 12 \\
\hline & $b$ & 0 & 16 & 1 & 17 \\
\hline & c & 3 & 10 & 0 & 13 \\
\hline & $d$ & 6 & 8 & 0 & 14 \\
\hline \multirow[t]{4}{*}{2} & $a$ & 3 & 7 & 0 & 10 \\
\hline & $b$ & 1 & 4 & 0 & 5 \\
\hline & $\mathrm{C}$ & 9 & 6 & 0 & 15 \\
\hline & $d$ & 4 & 9 & 0 & 13 \\
\hline \multirow[t]{2}{*}{3} & $a$ & 2 & 1 & 0 & 3 \\
\hline & $b$ & 2 & 1 & 0 & 3 \\
\hline \multirow[t]{2}{*}{4} & $a$ & 2 & 0 & 0 & 2 \\
\hline & $\mathrm{b}$ & 6 & 2 & 0 & 8 \\
\hline \multirow[t]{2}{*}{5} & $a$ & 2 & 1 & 0 & 3 \\
\hline & $\mathrm{b}$ & 2 & 1 & 0 & 3 \\
\hline \multirow[t]{2}{*}{6} & $a$ & 8 & 1 & 0 & 9 \\
\hline & $b$ & 11 & 4 & 0 & 15 \\
\hline \multirow[t]{2}{*}{7} & $a$ & 8 & 4 & 0 & 12 \\
\hline & $b$ & 3 & 3 & 0 & 6 \\
\hline & Jumlah & 75 & 87 & 1 & 163 \\
\hline & $\%$ & 46 & 53,4 & 0,6 & 100 \\
\hline
\end{tabular}

Tabel 6 diatas menunjukkan bahwa secara individu jenis-jenis kesalahan yang daialami mahasiswa dari total keseluruhan kesalahan yang dilakukan mahasiswa dalam menjawab soal kalkulus II terdapat 46\% mahasiswa mengalami miskonsepsi, 53,4\% mahasiswa tidak tahu konsep, dan hanya $0,6 \%$ mahasiswa menjawab soal dengan menebak (lucky guess). Miskonsepsi sebesar 46\% merupakan persentase yang sangat besar yang memiliki potensi akan terus terjadi ketika mahasiswa mempelajari matakuliah yang lainnya. Sedangakan 54\% mahasiswa tidak tahu konsep dan seorang mahasiswa menjawab dengan menebak, banyak factor yang mempengaruhi ketidaktahuan konsep tentang kalkulus ini diantaranya adalah kemamuan awal matematika atau materi prasyarat yang mungkin mereka belum menguasai dengan baik.

\section{Identifikasi Miskonsepsi Mahasiswa secara individu}

Rata-rata nilai CRI yang menjawab benar (CRIB) dan yang menjawab salah (CRIS) serta rasio mahasiswa menjawab benar (rb) dan rasio siswa yang menjawab salah dapat dilihat pada tabel 7 berikut ini.

Tabel 7.

Rata-rata Nilai CRI

\begin{tabular}{|c|c|c|c|c|c|}
\hline No & Konsep & $\begin{array}{l}\text { No } \\
\text { Soal }\end{array}$ & CRIB & CRIS & rb \\
\hline 1 & $\begin{array}{l}\text { Teknik integral } \\
\text { subtitusi }\end{array}$ & 1a & 4,60 & 1,93 & 0,25 \\
\hline 2 & $\begin{array}{l}\text { Teknik integral } \\
\text { fungsi rasional }\end{array}$ & $1 b$ & 4,00 & 0,69 & 0,20 \\
\hline 3 & $\begin{array}{l}\text { Teknik integral } \\
\text { fungsi } \\
\text { trigonometri }\end{array}$ & $1 c$ & 4,00 & 1,33 & 0,40 \\
\hline 4 & $\begin{array}{l}\text { Teknik integral } \\
\text { partial }\end{array}$ & $1 d$ & 3,67 & 2,00 & 0,30 \\
\hline 5 & $\begin{array}{l}\text { Turunan fungsi } \\
\text { eksponensial }\end{array}$ & $2 a$ & 4,00 & 1,80 & 0,50 \\
\hline 6 & $\begin{array}{l}\text { Turunan fungsi } \\
\text { bilangan natural }\end{array}$ & $2 b$ & 3,73 & 1,00 & 0,75 \\
\hline 7 & $\begin{array}{l}\text { Turunan fungsi } \\
\text { logaritma } \\
\text { natural }\end{array}$ & $2 c$ & 4,40 & 2,60 & 0,25 \\
\hline 8 & $\begin{array}{l}\text { Turunan fungsi } \\
\text { eksponensial } \\
\text { umum }\end{array}$ & $2 d$ & 3,43 & 2,00 & 0,35 \\
\hline 9 & $\begin{array}{l}\text { Turunan partial } \\
\text { dan nilai } \\
\text { turunan partial. }\end{array}$ & $3 a$ & 3,76 & 2,00 & 0,85 \\
\hline 10 & $\begin{array}{l}\text { Turunan partial } \\
\text { dan nilai } \\
\text { turunan partial }\end{array}$ & $3 b$ & 3,82 & 2,00 & 0,85 \\
\hline
\end{tabular}

Jurnal "Mosharafa", Volume 6, Nomor 2, Mei 2017 


\begin{tabular}{|c|c|c|c|c|c|}
\hline 11 & $\begin{array}{l}\text { Menentukan } \\
\text { nilai integral } \\
\text { rangkap dua } \\
\text { atas daerah } \\
\text { persegi panjang }\end{array}$ & $4 a$ & 4,11 & 3,00 & 0,90 \\
\hline 12 & $\begin{array}{l}\text { Nilai integral } \\
\text { rangkap dua } \\
\text { atas daerah } \\
\text { bukan } \\
\text { persegipanjang }\end{array}$ & $4 b$ & 4,00 & 2,75 & 0,60 \\
\hline 13 & $\begin{array}{l}\text { Gambar grafik } \\
\text { fungsi }\end{array}$ & $5 a$ & 3,71 & 2,00 & 0,85 \\
\hline 14 & $\begin{array}{l}\text { Aplikasi integral } \\
\text { rangkap dua }\end{array}$ & $5 b$ & 3,76 & 2,67 & 0,85 \\
\hline 15 & $\begin{array}{l}\text { Persamaan } \\
\text { Diferensial orde } \\
\text { satu }\end{array}$ & $6 a$ & 3,64 & 3,00 & 0,55 \\
\hline 16 & $\begin{array}{l}\text { Persamaan } \\
\text { diferensial orde } \\
\text { satu }\end{array}$ & $6 b$ & 3,80 & 2,60 & 0,25 \\
\hline 17 & $\begin{array}{l}\text { Persamaan } \\
\text { diferensial orde } \\
\text { dua }\end{array}$ & $7 a$ & 3,62 & 2,67 & 0,40 \\
\hline 18 & $\begin{array}{l}\text { Persamaan } \\
\text { diferensial orde } \\
\text { dua }\end{array}$ & $7 b$ & 3,27 & 2,60 & 0,75 \\
\hline
\end{tabular}

Dari hasil perbandingan antara CRI jawaban benar dan salah dengan rasio antara siswa yang menjawab benar pada setiap konsep, dapat dianalisis bahwa kebanyakan siswa masih cenderung mengalami miskonsepsi pada konsep turunan fungsi logaritma natural, Integral rangkap dua atas daerah persegipanjang dan bukan persegipanjang, aplikasi integral rangkap dua, persamaan diferensial orde satu dan dua. Sedangkan kecenderungan mahasiswa yang tidak tahu konsep terdapat pada kategori teknik integral subtitusi, fungsi rasional, fungsi trigonometri dan parsial, turunan fungsi transenden dan turunan parsial.

\section{Penutup}

Berdasarkan hasil analisis data, ketika memecahkan masalah kalkulus II, 46 \% mahasiswa mengalami miskonsepsi, 53,4\% mahasiswa tidak tahu konsep dasar, dan 0,6\% mahasiswa menjawab soal dengan menebak. Miskonsepsi terjadi mahasiswa terutama pada konsep turunan fungsi logaritma natural, Integral rangkap dua atas daerah persegipanjang dan bukan persegipanjang, aplikasi integral rangkap dua, persamaan diferensial orde satu dan dua. Mahasiswa yang tidak tahu konsep terdapat pada materi teknik integral subtitusi, fungsi rasional, fungsi trigonometri dan parsial, turunan fungsi transenden dan turunan parsial. Banyak mahasiswa yang mengalami miskonsepsi dan tidak tahu konsep mengenai materi Kalkulus II dibanding yang mengetahui konsep. Maka dapat dikatakan bahwa banyak konsep yang tidak dimengerti oleh siswa.

Sebagian besar mahasiswa tertarik dengan materi Kalkulus II namun tidak ditunjang dengan pengetahuan awal mereka yang masih minim. Perlu adanya kajian lebih dalam menganalisis faktorfaktor yang menyebabkan terjadinya miskonsepsi dengan mempertimbangkan kemampuan awal matematika mahasiswa. Perlu adanya kajian yang berkaitan dengan Implementasi model pembelajaran yang telah dikembangkan dengan baik dan tepat menarik siswa agar berminat mempelajari Kalkulus II serta mengurangi terjadinya miskonsepsi dan tidah tahu konsep. Bagi pengajar dapat mempertimbangkan metode CRI sebagai 
metode untuk mengidentifikasi konsepkonsep lainnya yang terjadi pada siswa yang didiknya di setiap proses akhir pembelajaran.

\section{Daftar Pustaka}

Ausubel, D., Novak, J., \& Hanesian, H. (1978). Educational Psychology: A Cognitive view (2nd Ed.) New York: Holt, Rinehart \& Winston.

Brown, G. \& Quinn, R.J. (2006). Algebra student's difficulty with fractions: an errors analysis. AMT, 62(4), 28-40.

Clement, J (1982). Algebra word problems solution: Thought processes underlying a common misconception. Journal for Research in Mathematics Education, 13(1), 16-30.

Clement, J., Lochhead, J., \& Monk, G. S. (1981). Translation Difficulties in learning mathematics. The American Mathematical Monthly, 88(4), 286290.

Joseph D. N (1987). Misconceptions and Educational Strategies in Science and Mathematics. Proceedings of the International Seminar 2nd, Ithaca, New York.

Klammer, J., (1998), An Overview of Techniques for Identifying, Acknowledging and Overcoming Alternate Conceptions in Physics Education, 1997/1998 Klingenstein Project Report, Teachers CollegeColumbia University.

Luneta, K., Makonya, P.J. (2010). Learner Errors and Misconceptions in Elementary Analysis: A Case Study of a
Grade 12 Class in South Africa. Acta Didactica Napocensia, 3(3), 35-46.

Riccommini, Paul J (2005). Identification and Remediation of Systematic Error Patterns in Subtraction. Learning Disability Quarterly, 20, 233-242.

Ryan, J., \& McCrae, B. (2005). Subject Matter Knowledge: Mathematical Errors and Misconceptions of Beginning Pre-Service Teachers. Proceedings of the 29th annual conference of the International Group for the Psychology of Mathematics Education. Melbourne, Australia: PME.

Saleem Hasan, D. Bagayko, \& Kelley, E. L. (1999). "Misconception and the Certainty of Response Index (CRI)". Phys. Education, 34(5), 294-299.

Suparno, P. (2005). Miskonsepsi dan Perubahan Konsep Pendidikan Fisika. Yogyakarta: Gramedia Widiasarana Indonesia.

Van den Berg, E. (1991). Miskonsepsi Fisika dan Remediasi.UKSW. Salatiga

\section{Riwayat HidUP PENULIS}

\section{Abdul Mujib, S.Pd., M.PMat.}

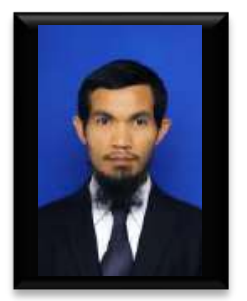

Staf pengajar di Universitas Muslim Nusantara AlWashliyah. Studi S1 Pendidikan Matematika Universitas Muslim Nusantara Al-Washliyah, Medan, lulus tahun 2006; S2 Pengajaran Matematika Institut Teknologi Bandung, Bandung, lulus tahun 2011; dan S3 Pendidikan Matematika Universitas Pendidikan Indonesia, Bandung, sampai dengan sekarang. 